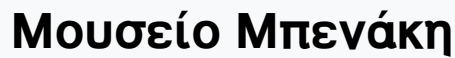

A Singular Antiquity: Archaeology and Hellenic Identity in Twentieth-Century Greece

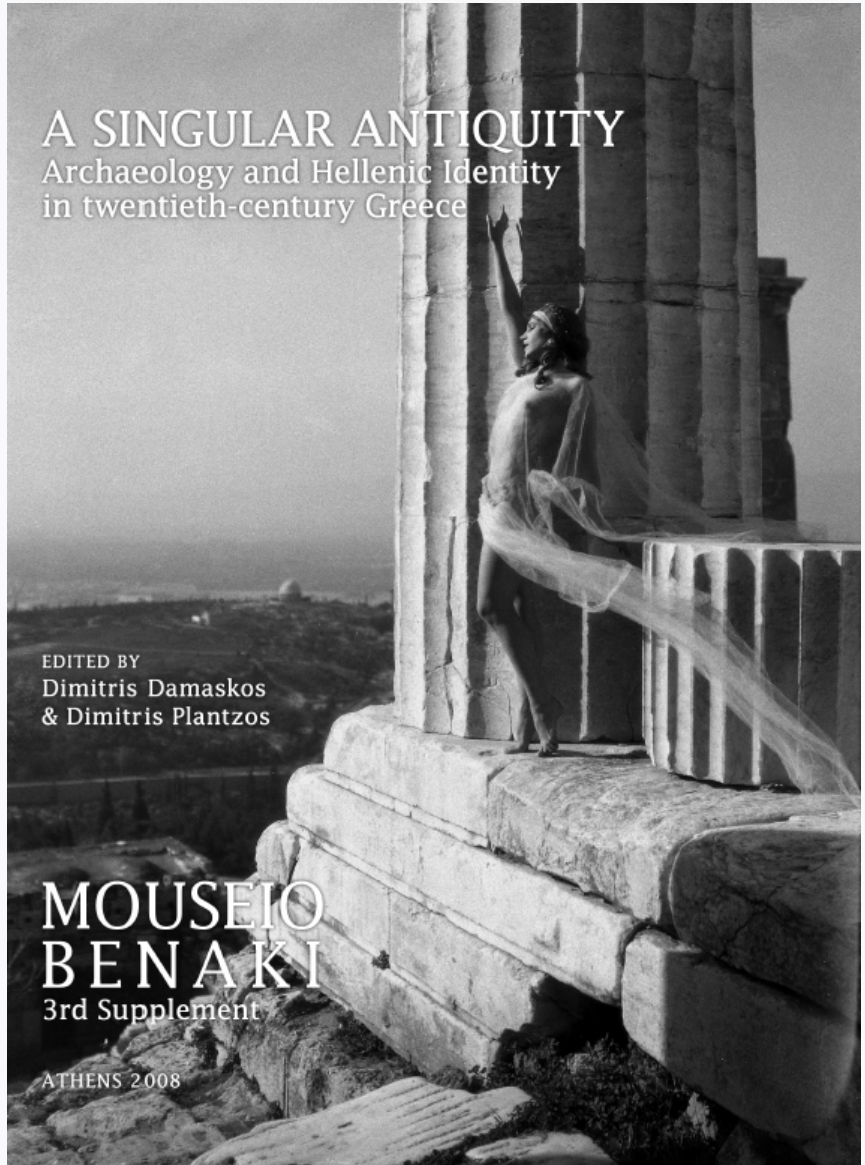

\section{Venetian monuments in Crete: a controversial heritage}

Olga Gratziou

doi: $10.12681 /$ benaki.18008

Copyright (c 2018, Olga Gratziou

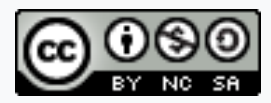

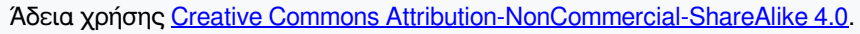

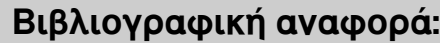

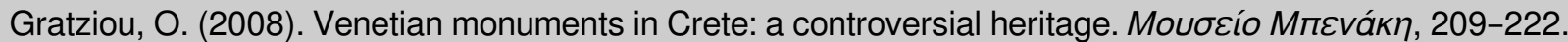
https://doi.org/10.12681/benaki.18008 


\section{Venetian monuments in Crete: a controversial heritage}

IT IS WELL KNOWN THAT attitudes to historical monuments in present-day Greece have been determined by the importance antiquity had for the emergent Greek state in the nineteenth century. As the most pre-eminent historic past of the small Balkan country, which emerged from an armed uprising against the senescent Ottoman Empire, antiquity was useful to announce, in all its glory, the nation's unity and to legitimize its claim to independence in the eyes of the European powers. When towards the end of the nineteenth century the interest of Western European scholars, but also of Greek state institutions and intellectuals, began to turn to the medieval monuments, these too were finally mobilized to show the direct relationship between contemporary Greeks and their ancient ancestors, ensuring the necessary intermediary link to a centuries-long chain of Greek civilization.

The much discussed tripartite ordering of Greek history from antiquity via Byzantium to the modern period (beginning with the Greek Revolution in 1821), militated against the more or less monumental remains of buildings constructed on Greek soil in times of foreign domination being included in the monuments considered representative of the culture and identity of the nation. Roman, Frankish, Venetian and Ottoman monuments were not thought of as actual monuments; rather they were regarded with indifference or even hostility for a large part of the twentieth century. A reference to the Venetian walls of Herakleion in Crete in a nineteenth-century historical novel is revealing. The novel is by Spyridon Zambelios, a scholar whose contribution to forming the national memory was of decisive importance. ${ }^{1}$ In establishing the loca- tion and time-frame for his narrative, which is set among Greeks and Venetians in Crete under Venetian rule, he describes the capital, Candia, as being disfigured by its Venetian walls which resemble 'a crown of thorns.'

The hyperbolic nature of the comparison served the purposes of the tale which was to follow, in which the bravery and uncompromising nature of the Cretans and the treachery and cunning of the Venetians is stressed. It prepared the reader for a dramatic turn in the story, yet expressed something over and above this, which is in fact characteristic of the whole book. It emphasized the spirit of independence shown by the Greeks in the face of foreign conquerors, a topical issue in the nineteenth century when Crete was still under Ottoman rule and when successive uprisings had attempted to unite it with the Greek state. Yet the aversion to foreign monuments in the country, expressed by Zambelios with literary means, had wider resonance; a large part of the educated Greeks felt the same way. Both the Greek Government and the young Cretan Republic had eyes for and money to spend only on what could be described by right as national monuments, monuments of their ancestral national history. The monuments which recalled the periods of foreign domination, which were much more works of 'foreign' cultures, were condemned to damnatio memoriae; they had to be forgotten, consequently they were not monumenta.

It was an ideological process which did not entirely correspond with the legislative and institutional arrangements made for the protection of monuments. However, from the first Archaeological Law of 1834, drafted by the Bavarian Georg Ludwig von Maurer, in the Vice Regency of 


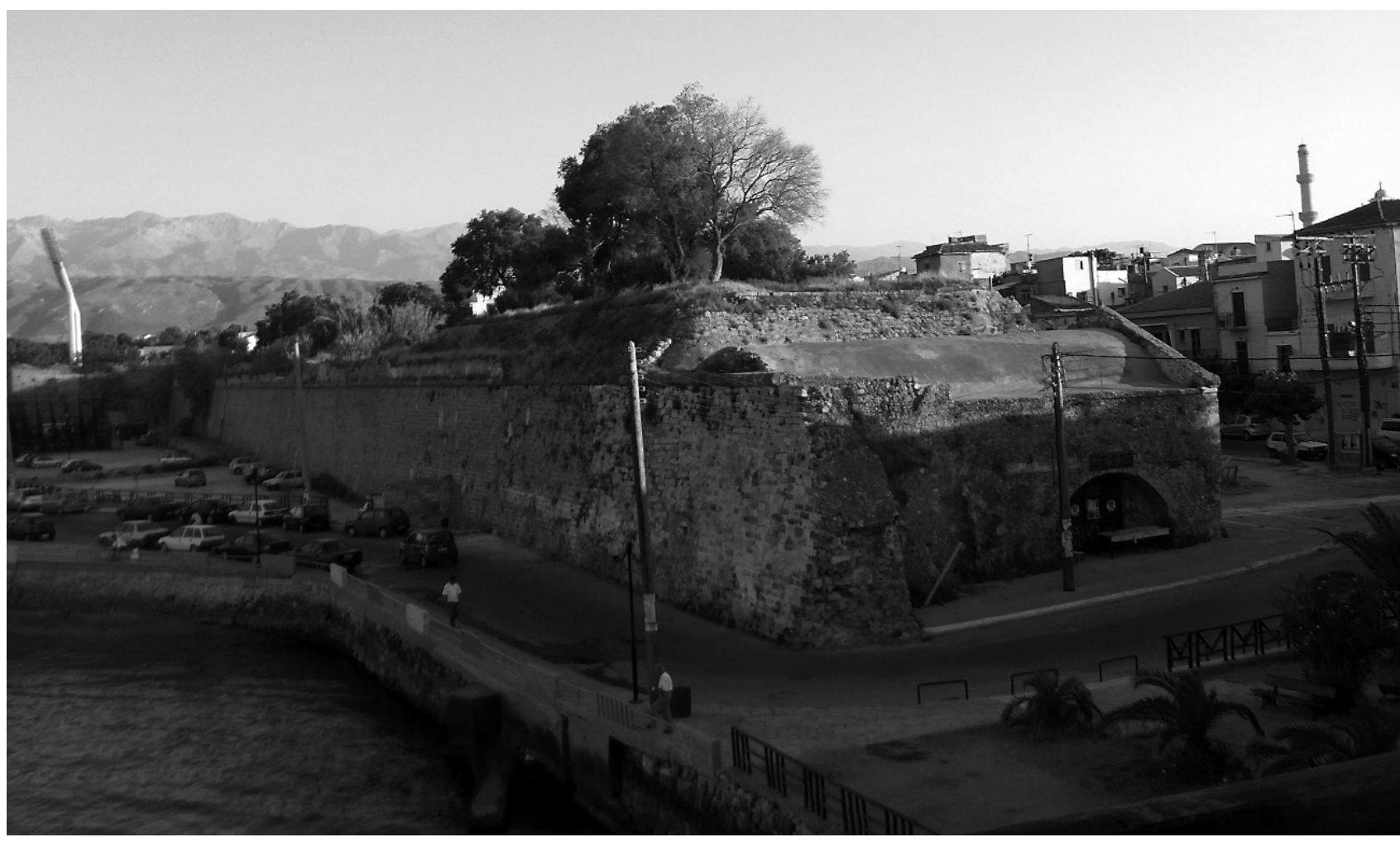

Fig. 1. Chania, Sabbionara gate. A part of the Venetian wall has been demolished to let the street pass through (photo: author).

King Otto, to the codification of its occasional revisions in 1932, the legislation spoke of antiquities as well as 'works of the ancestors of the Greek people' ${ }^{3}$ and there is no doubt that the overwhelming majority of those charged with implementing the legislation were not ready to include monuments that were neither ancient, nor Byzantine nor even 'post-Byzantine' in the familiar pattern of the history of the nation. Even though from the twenties on certain administrative regulations included building complexes from the Venetian and Ottoman periods, especially forts, in the buildings listed for preservation henceforth, these monuments were never actually integrated in the historic landscape of their region. They remained in a dilapidated state, without active protection, in run-down areas. The reasons for this were not, of course, entirely ideological, but rather mainly financial. The priorities according to which funds available for monuments were spent were determined by needs arising from the ideological framework for preservation and display of the ancient monuments, the rescue digs due to rebuilding in modern towns and the Western European interest in these monuments, whether

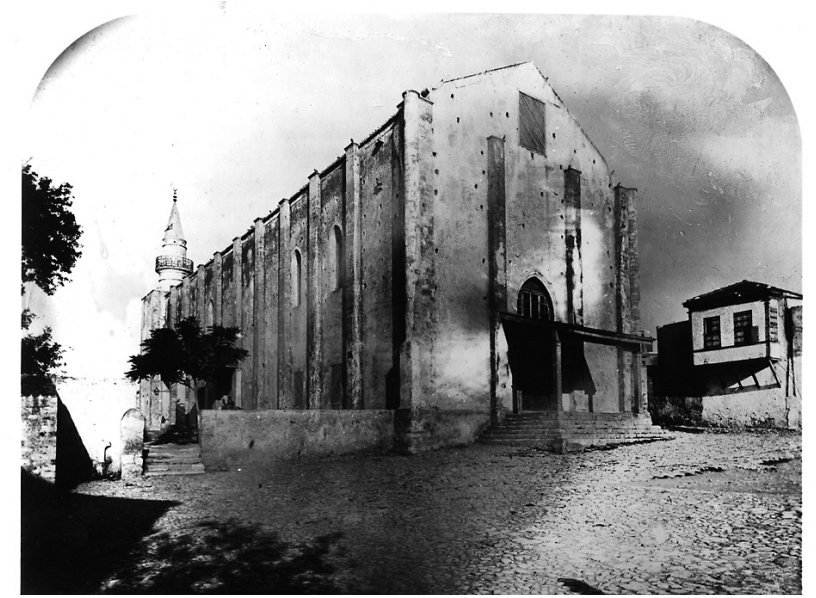

Fig. 2. Herakleion, San Salvatore, photographed by Gerola between 1900-1902.

manifested as scholarly activity by foreign archaeological institutions in Greece, or demand from tourism.

Economic development and the desire to modernize the urban environment have led to large-scale demolition of historical buildings and, of course, this problem is not confined to Greece. In Crete reconstruction work began 


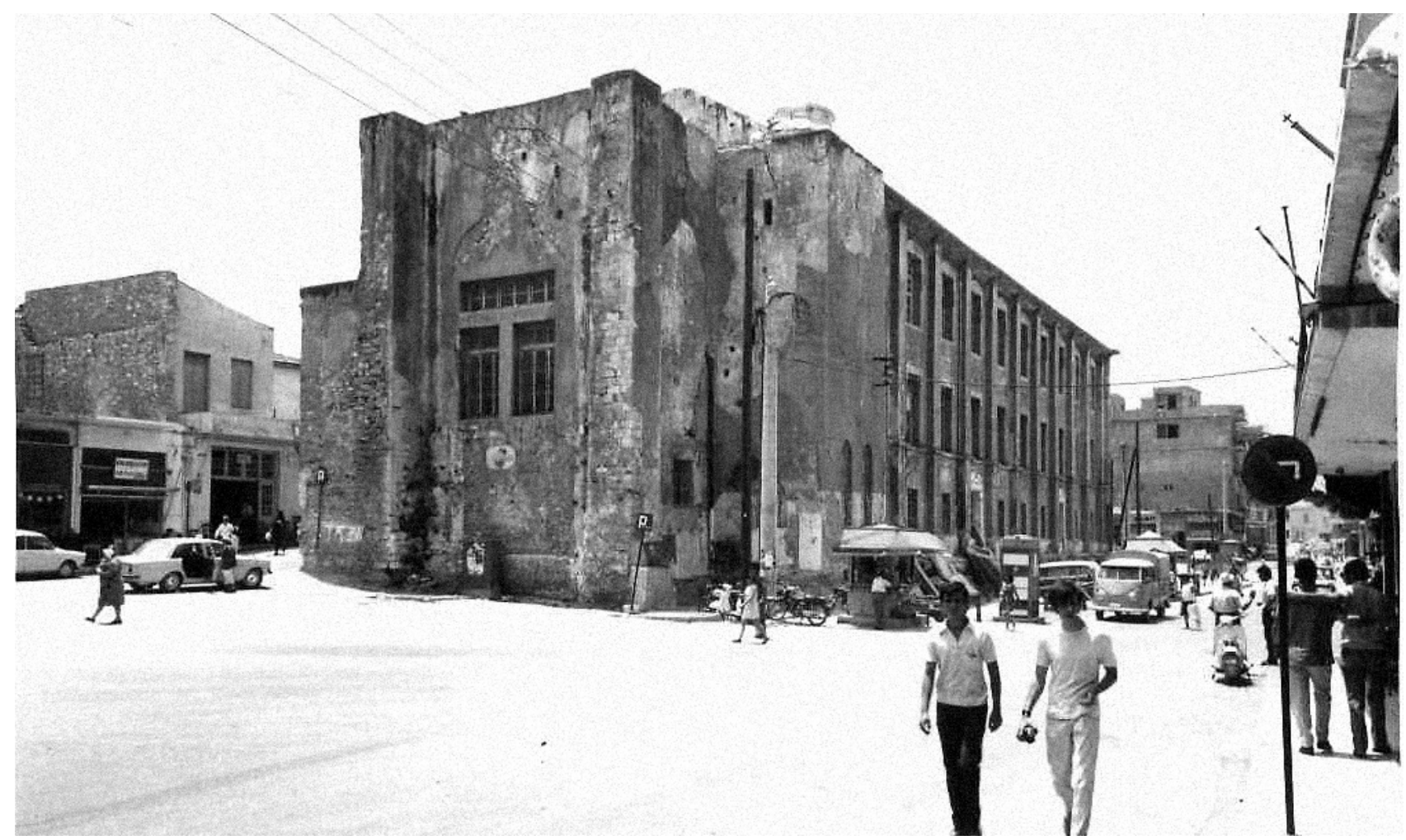

Fig. 3. Herakleion, San Salvatore before demolition, 1972.

as early as the end of the Ottoman period, when the Ottoman authorities were trying to modernize, and increased as soon as Crete won its independence. An example of this modernization is the construction of the Municipal Market in Chania, in itself an important piece of architecture of its time, which involved demolishing of the piatta-for$m a$ of the impressive sixteenth-century Venetian fortifications. ${ }^{4}$ There was extensive demolition, especially between the wars, both for road widening and for reconstruction purposes. Thus in Herakleion and Chania parts of the marvellous sixteenth-century fortification walls were demolished to make way for arterial routes (fig. 1) and a large number of private houses were knocked down, parts of which dated back to the Venetian period. Though we have no direct evidence as regards the latter, we can deduce that this was the case from two indicators. The details of some of these houses had been photographed in the early twentieth century by the Italian scholar Giuseppe Gerola; by mid-century when the first attempts were made to preserve monuments from the Venetian period some architectural members, lacking documented provenance, were picked up, which later (in 1953) were gathered together in the newly established Historical Museum of Crete in Herakleion. These remains leave no doubt that some noble residences of the Venetian period had been preserved until the twentieth century and then demolished before their importance as architectural or historic monuments was recognized. So when, in the late twentieth century, the heritage of the Venetian period began to acquire greater significance - because of the historical background it gave to Greece's new European orientation - many of these monuments were no longer around.

The last big demolition job was carried out by the state, though in the face of protest. It was especially barbaric inasmuch as it happened late in the day (1972), when Greece too had agreed to record and protect its more recent urban architecture, under the common European policy on the architectural heritage of Europe. The building which was knocked down was the large church of San Salvatore, built by the Augustinian order in the fourteenth century, and situated in the historic centre of Herakleion (fig. 2). The church represented the severe style of Gothic architecture 


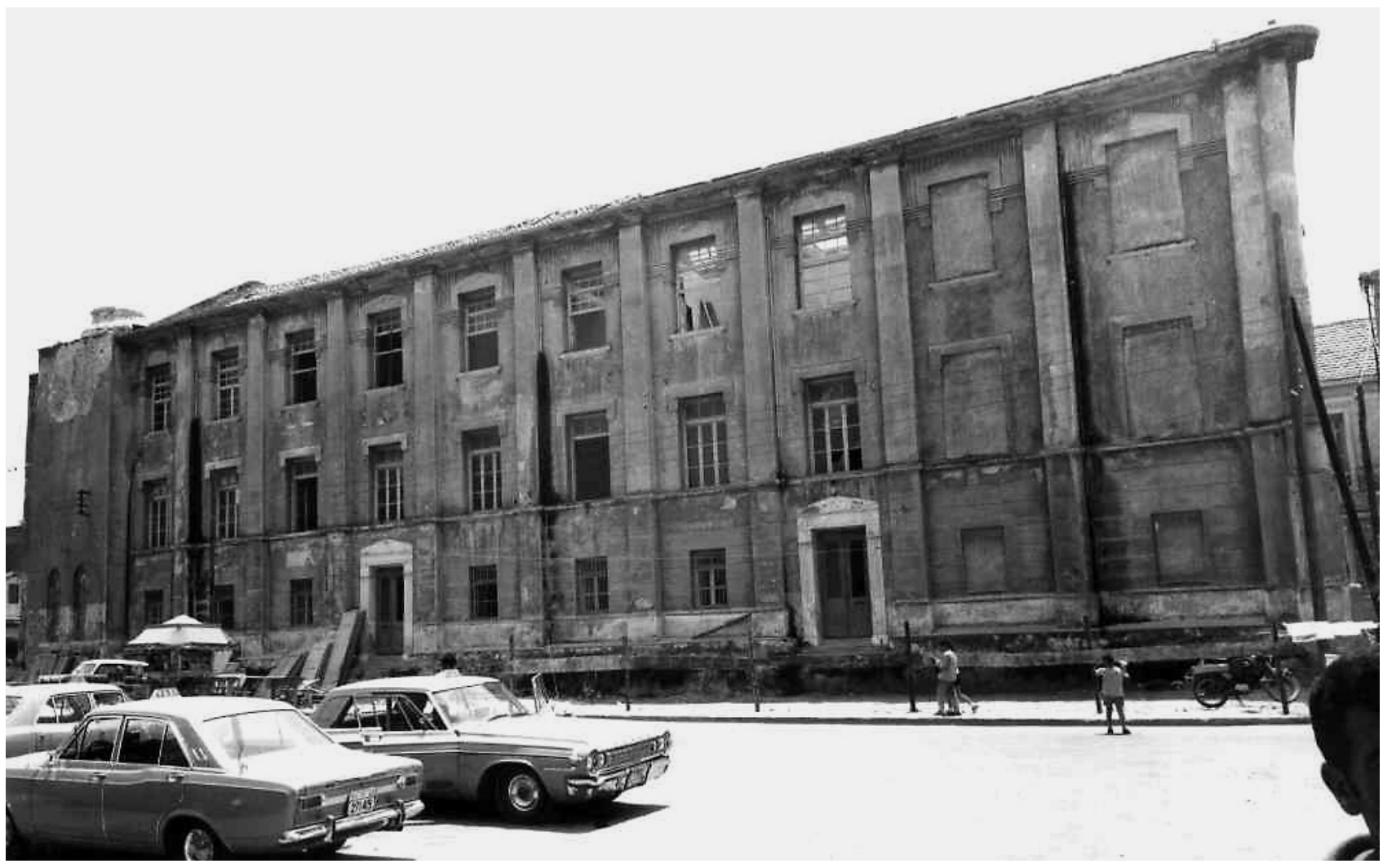

Fig. 4. Herakleion, San Salvatore during the demolition 1972.

adopted by the mendicant orders of the Roman Catholic Church. The building had many similarities with the Eremitani Church in Padua, which also belonged to the Augustinians. Moreover it was the only remaining Western-style medieval church on Greek soil which had preserved its entire shell until then. Naturally it was a deserted building, which had been unused for about a decade.

However, the uses to which it had previously been put are very enlightening as regards the way in which it became degraded in the minds of the local population. When the Venetians left Crete the building was abandoned by the Capuchin monks who were currently occupying it. Under the Ottomans it was turned into a mosque belonging to the Valide Sultan (the mother of the sultan). It underwent the necessary liturgical changes and was smartened up with, among other things, an exceptional revetment of ceramic tiles on the walls. Any sculptural or painted decoration associated with Christian use was removed and a tall minaret replaced the Gothic bell tower. It was known henceforth as the Valide Mosque, a name which continued to be used into the twentieth century. Once the Turks had left Crete, the building - a large one for such a small town - was deconsecrated. The Islamic decoration was removed, the minaret demolished and a use was sought for the shell, which remained in extremely good condition. It was turned into a school with the addition of an internal skeleton of reinforced concrete to make it into a three-storey building. The necessary windows were knocked through (fig. 3). In the sixties, after an earthquake, the building was judged unsafe and abandoned, given that in the meantime purpose-built schools had been constructed. From the moment it became unfit for purpose, it became useless in the eyes of the public. Up to that time no attempt had been made to show that the building had any value to Greece's culture or history, in other words that it was a 'monument'. Just a few specialists were aware of it. And so people in the neighbourhood began to ask for the massive 'useless' building to be demolished, to allow more sunlight into their homes. This was the time when the town's old, small-scale houses were being replaced by 


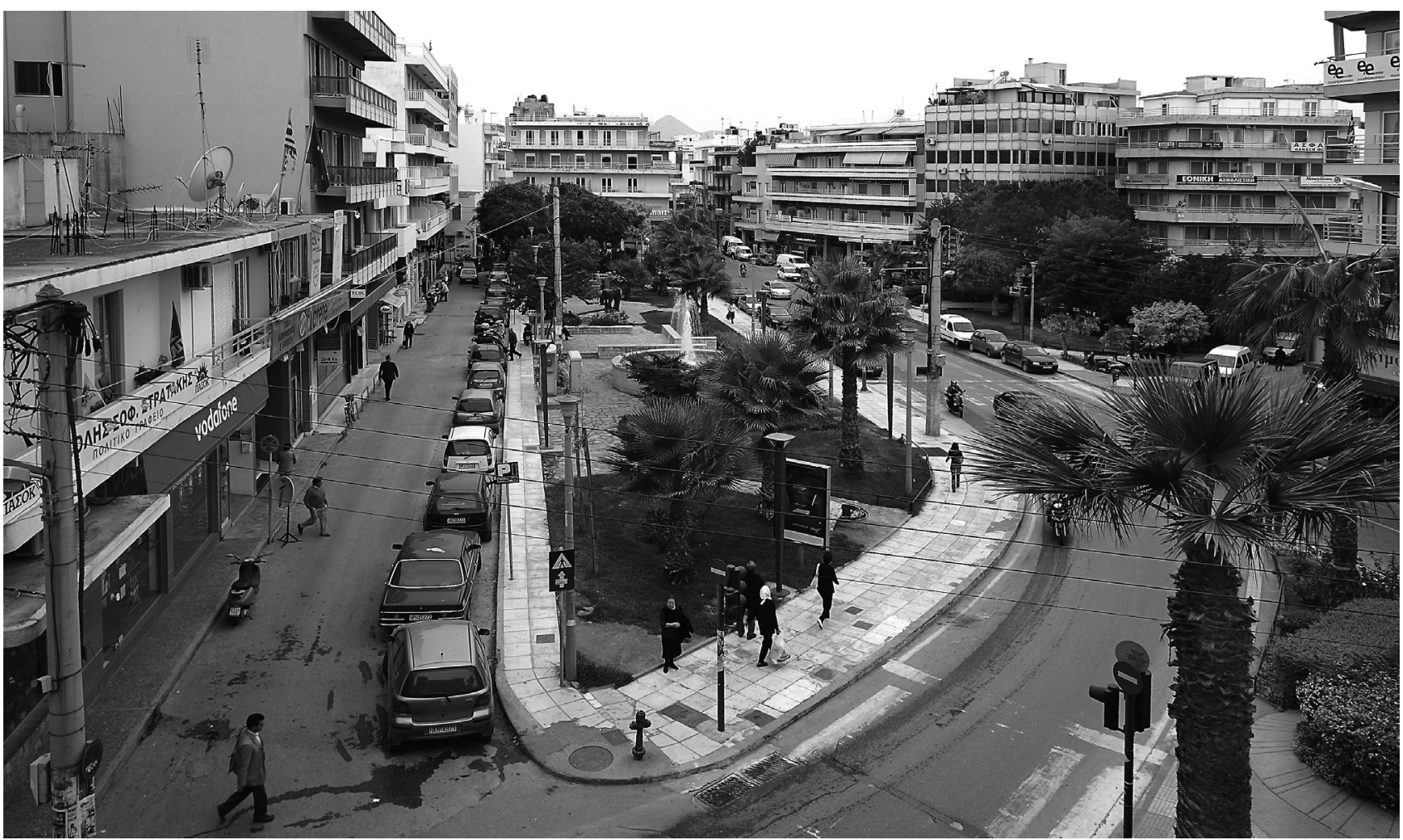

Fig. 5. Herakleion, Kornaros Square in place of San Salvatore (photo: author).

multi-storey blocks of flats whose new owners wanted to look out onto squares.

At that time a military junta ruled the country and local authorities were administered by officials appointed by the dictatorship. In 1970 these authorities decided to knock down the Valide Mosque on the grounds that it was a dilapidated building and an eyesore in the developing town. There was no initial reaction from the top brass in the Archaeological Service. On the other hand the country's intellectuals did react, which resulted in some of them going to court accused of insurgency. Given that engineering consultants confirmed the stability of the building's load-bearing fabric, this reaction obliged one member of the junta, Stylianos Pattakos, to call a meeting in Herakleion with local bodies and representatives of the Archaeological Service (which in the meantime had got behind the campaign to preserve and make use of the monument). The dictator listened to all sides and came to his conclusion: it was not a monument of Greek culture, so let it be demolished. The building was knocked down post haste, without excavation or other archaeological documentation. According to an eye-witness ${ }^{5}$ the bulldozers had difficulty in demolishing the massive stone structure (fig. 4).

The church's place was taken by a square which takes a large part of the traffic chaos in the busy town (fig. 5). The jerry-built seventies blocks of flats, which gained light and a view as a result of the monument's demolition, have already become run-down. However, nowadays both the town and the whole island are proud of what is a relatively recent period in their history by comparison with the mythical time of the Minotaur: the Venetian period when an important culture with European roots and a literature which marks the first highpoint in modern Greek civilization were developed. Thus the Municipal Council set up a modern monument in the middle of the square to commemorate this glorious moment: a bronze sculptural group of a popular pair of lovers, Erotokritos and Aretousa. They are protagonists of the Erotokritos, a poetic masterpiece of Cretan literature, written in the early seventeenth 


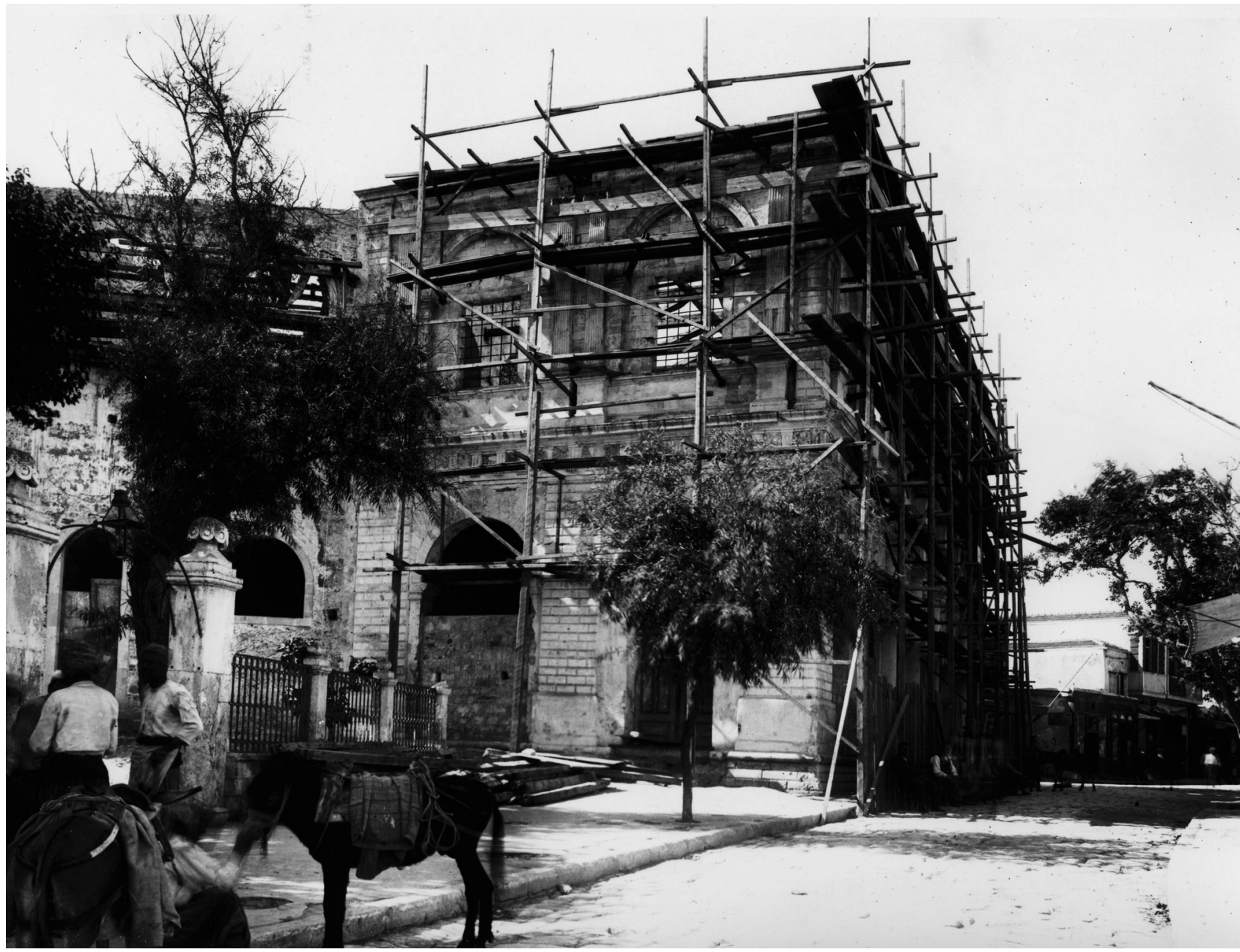

Fig. 6. Herakleion, Venetian loggia, beginning of the 17th century, photographed by Gerola between 1900-1902.

century by the Veneto-Cretan Vincenzos Cornaros. And the square was given the name of the poet!

An example of a Venetian monument whose destruction has been more formally redressed is the loggia of the Venetian nobles, once situated at the heart of the capital of the Regno di Candia. It marked the spot where the commercial ruga magistra leading from the harbour met the town square. On the other side of the square rose the ducal palace and the seat of the island's military administration, with the ducal church of San Marco just a few metres to the south and the monumental fountain, with which the town centre was embellished in 1630 , in the middle of the square. In other words it was in the commercial and administrative centre of the flourishing town that was Candia in the seventeenth century, the town itself having been created with a view to elegance according to the standards of the day and to being comparable with the great Venetian metropolis. The loggia was one of the few Venetian public buildings to survive into the early twentieth century, when Gerola photographed it (fig. 6). ${ }^{6}$ At that time it was considered that the damage it had sustained would be difficult to repair and first the upper storey was knocked down and then the whole building. But from the sixties onwards the municipal authorities began to set work in motion to construct a faithful copy, which was finally completed around 1980 . Thus the new stone-built construction with its two-storey Palladian arcades on the façade now houses Herakleion's town hall (fig. 7). The reconstruction was given an award in 1987 by Europa Nostra, the European organization for cultural heritage. The replica is surrounded by tarmac in a 


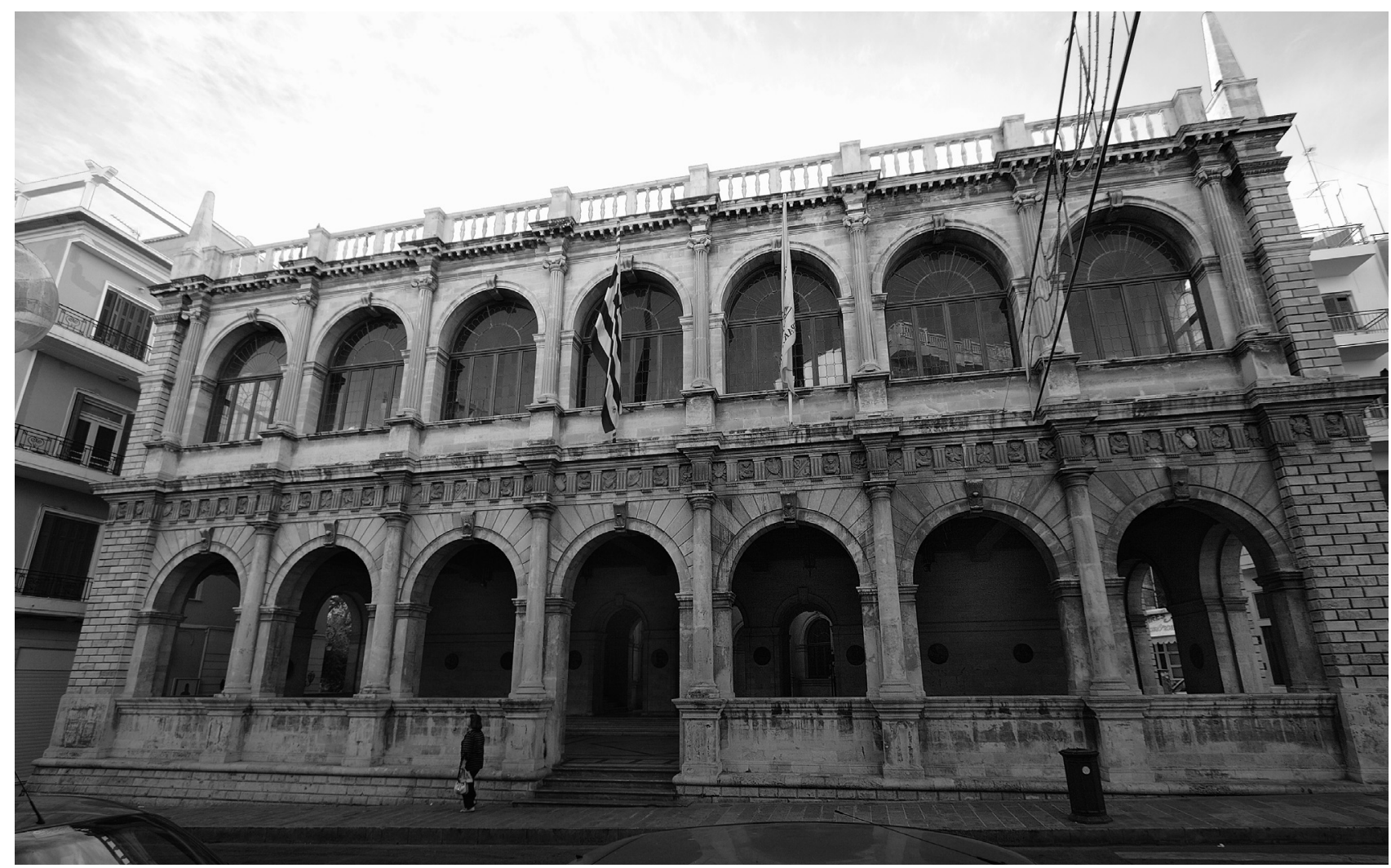

Fig. 7. Herakleion, Town Hall in place of the Venetian loggia. Rebuilt in the eighties (photo: author).

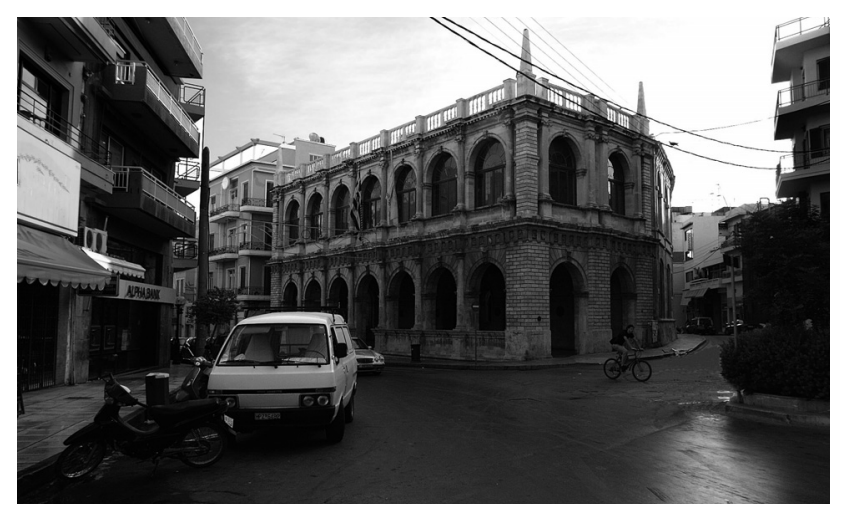

Fig. 8. Herakleion, as fig. 7, view from southwest (photo: author).

town without pavements. Ugly residential blocks, all built since 1960, now crowd around it (fig. 8).

Of the other buildings from Candia's town square the church of San Marco has been preserved in part and the Morosini fountain with its four lions, which has undergone repeated remodelling (fig. 9). The almost complete disappearance of the centre of a European town of the early modern period is an interesting historical phenomenon in itself, which throws light on the fate of Venetian monuments in Crete. It is not just a case of simple indifference or neglect on the part of more recent generations with regard to old buildings. This example should rather be seen as illustrating the violent overthrow of real and symbolic values in the island's society on more than one occasion. It witnesses to the lack of continuity in ownership and authority; the repeated abandonment of state and private property. In the final analysis it is a testimony to the history of Crete, in which rulers and communities with different cultural traditions and different value systems have looked down their noses at what their predecessors left behind.

The succession of value systems is clearly illuminated by the history of the uses to which ecclesiastical monuments have been put, as we have seen from the fate of San Salvatore. The identification of the nation with the Orthodox Church and the close relationship between the state and the church in modern Greece has contributed to the 

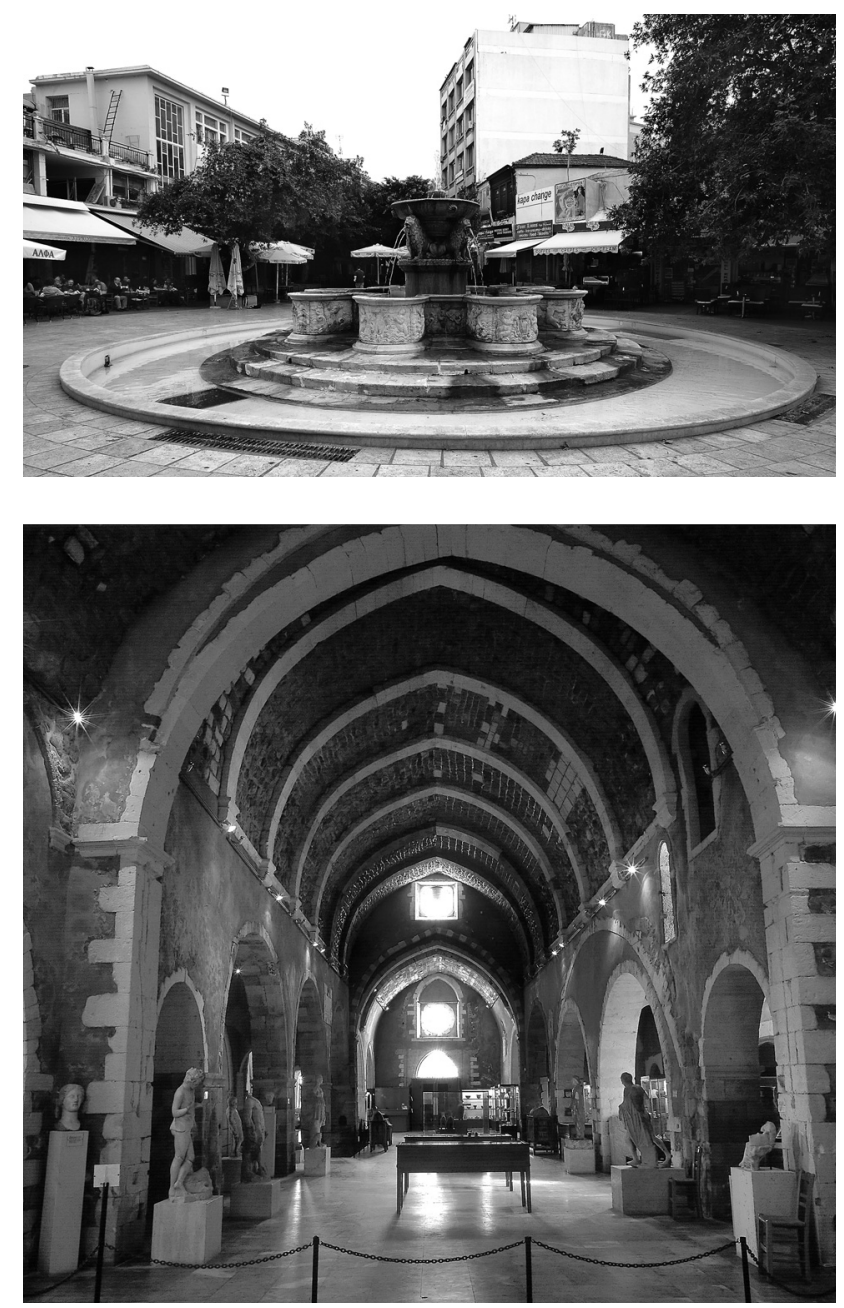

Fig. 9. Herakleion, Morosini Fountain, first half of the 17th century (photo: author).

Fig. 10. Chania, St Francis housing the Archaeological Museum (photo: author).

hostility felt towards churches of 'other faiths'. From the time of the Greek War of Independence, which led to the founding of the Greek state, mosques and their minarets were seen as symbols of slavery. They were demolished in every area incorporated into the Greek state after long years of Ottoman domination, before anyone could work out how old they were then, or assess their architectural or historic importance. Moreover at that time the concept of a 'monument' was invoked only with reference to the monuments of antiquity. The attitude to the Catholic churches in Crete was not much better after the Autonomy (1898-1913) and the island's final incorporation into
Greece in 1913, given that from the late seventeenth century on most of them had been converted into mosques. This conversion scarcely bothered the religious sensibilities of the majority of the local Orthodox population - especially given that the religious tolerance, which the Ottomans had shown to the Orthodox population, had been accompanied by severe condemnation of those who took a pro-Venetian stance during the long Cretan war in the seventeenth century. Once the Turks had left in the early twentieth century the mosques lost their religious use. There was no surviving memory of cult connected with them in the population. Given their size and the quality of their fabric, they were put to a variety of uses by both the authorities and individuals, to whom a number of these former churches belonged. Many of them have yet to be declared historic monuments.

Apart from the characteristic story of San Salvatore there are several more cases worth noting because they shed light on changing attitudes to monuments by the very state bodies responsible for the protection of historic monuments. St Francis in Herakleion, probably the largest and most sumptuous Latin church in Crete, suffered serious damage from earthquakes after it became a mosque and was demolished in the nineteenth century. One of its side chapels continued to house the mosque up to the end of the Ottoman period? Later this space was used as a store-room for archaeological finds. In the thirties this too was demolished to clear the area on which the Herakleion Archaeological Museum was built. During recent work to build an extension to the museum, a rescue dig brought to light remains of the church which led, not before time, to the plans being changed in order to incorporate the traces of the Franciscan church into the new wing of the museum.

The notion of using historic buildings as museums was very widespread in the sixties. It was considered compatible with historic structures which had long since lost their original function while at the same time solving the acute problem of housing the antiquities being brought to light on a daily basis in the excavations resulting from postwar reconstruction. It was planned to turn St Francis in Chania into a museum. The Archaeological Service, faced with this proposed conversion, was concerned as to the poor state of the monument which, after the withdrawal of the Turks, had housed shops and then the town's first cinema (fig. 10). So the sitting of the Archaeological Museum in the Franciscan church represents a big advance 


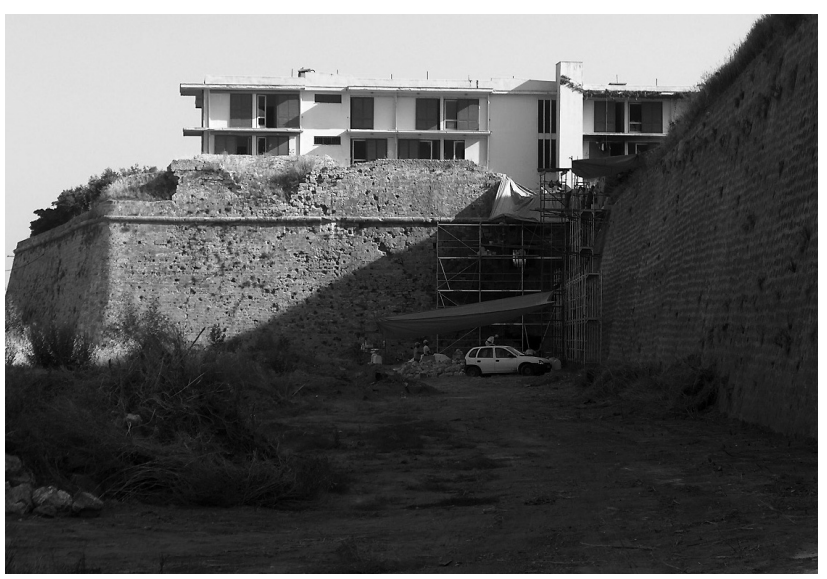

Fig. 11. Chania, Hotel Xenia on the seafront bastion of the Venetian wall. Before demolition, 2007.

as regards the protection and enhancement of a medieval monument. Nevertheless the restoration was done without any prior study or documenting of the extensive building history of the complex, with unauthorized use of concrete and the creation of an entirely new pseudo-Romanesque doorway at the east end, where the presbytery had once stood, as there was no access on the other sides of the building which belonged to various owners.

In that same period the Rethymnon loggia, the work of Michele Sanmicheli, was converted into an archaeological museum. ${ }^{8}$ By the standards of the day this was a great act of conservation. It should be noted that it happened just a few years after the demolition of the neighbouring Venetian clock tower, which - although dilapidated - had been preserved until the mid-twentieth century.

Despite some mistakes and awkward solutions these efforts show that in the course of the twentieth century the attitude to monuments of the Venetian period has changed. Of course, it should be stressed that changes in perceptions as to what constitutes a monument and what is likely to be the most suitable method of conservation or use for it are ongoing in modern societies and a variety of factors, many of which are ideological and political, come into play in this respect. However, there is no shortage of rational, scientific approaches too, which are interwoven with and interdependent on the ideological parameters. Even if we take all this into account, we can only describe the change in attitude to monuments in Greece in the course of the twentieth century as spectacular; even al- lowing for the fact that their preservation and conservation has been hampered by financial restrictions and their integration into the cityscape or the landscape has not always been successful.

One factor which contributed to the change in attitude towards monuments in the sixties was political rather than ideological. The upgrading of monuments was helped by their being linked with policy on tourism. The Archaeological Service benefited as a result of this policy. Staff numbers increased all over the country. The archaeologists were aware of all kinds of monuments in the region where they were working, in addition to those for which they were directly responsible. They also had a broader and more scientific perception of the concept of a monument than other authorities, as we may assume that they were following corresponding developments in the rest of Europe. However, they did not have the power to translate that perception into active protection.

In the sixties many regional archaeological museums were set up, including those which were housed in buildings of the Venetian period in Crete. Byzantine churches were restored and many Byzantine wall-paintings were conserved all over the country. The Archaeological Service began to exercise control, if not altogether officially, over new building close to archaeological sites or important monuments. In 1965 an Ephorate for Contemporary and Modern Monuments was set up and began to record the architecture of nineteenth-century eclecticism. For the first time attention was paid to forts and uses were sought for them which would help to create a historical landscape by displaying them to advantage and exploiting them for tourist purposes.

Initially this policy of reuse affected few of the surviving forts and its results were debateable. It mainly consisted of constructing hotels within hill-top fortifications from the medieval and early modern periods. As well as highlighting the forts as places of value and upgrading their townplanning status, this construction activity caused drastic interventions in the monuments and their surroundings resulting in direct damage. The interesting thing about this process is that these hotels all belonged to the 'Xenia' programme, drawn up and administered by the state, in the form of the Greek National Tourism Organization, in order to promote high-class tourism. They were designed to high standards by some of the best architects of the time. The list includes buildings constructed in: the 
medieval fort at Arta, in the castle of Akronafplia in Nafplion, and on the site of the north-west battlements of the Venetian walls in Chania in Crete (fig. 11). The latter, built in the seventies, had an exceptional position overlooking the sea. Its forecourt was bounded by the wall itself. But its foundations destroyed the Venetian battlements and its outline was a radical change for the profile of the imposing monument, which until then had been preserved in excellent condition. The weak objections of the Archaeological Service could not prevent the construction of the hotel then on that advantageous public 'building site'. In any case, once it began to operate it was expected to benefit the whole town. And indeed the Xenia hotel, built on the Venetian walls in the Old Town of Chania, has helped improve a dilapidated area and introduce the protective practices and strict control over new builds, which have subsequently been implemented.

Nevertheless the Xenia programme has collapsed. The international chains of hotels which have overrun the country, the weaknesses in the state-run management of the Xenias, the multiplicity of smaller private hotels, most of which emerged from the new policy of subsidizing tourist businesses, led to the decline and eventual abandonment of the publicly owned Xenias before the end of the twentieth century. The empty shells of these once model hotels became, in the nineties, the subject of complaints to local authorities. The locals were demanding these 'useless' buildings be demolished, just as once they had demanded the destruction of the Gothic church of San Salvatore in Herakleion. In the summer of 2007 the Xenia in Chania was demolished in order to recreate the historic landscape and to return the Venetian fortification to the town as a green space for leisure! Before 1970 it was not even part of the town's historical self-image. It was a second-rate monument which nevertheless had to be maintained, but the fact that it remained intact was largely irrelevant, its archaeological investigation was thought to be superfluous and even its contribution to creating the cityscape was of no account. The demolition of the Xenia in 2007 was combined with a programme of restoration and display of the Venetian fortifications and the moat which, despite the destruction which had gone before, survived in large part. The programme has been set in train by the Archaeological Service but is broadly supported by the city authorities and the local community. The town is even proud of its Venetian walls and the reasons for this change in everyone's attitude are no longer simply to be found in the desire to promote tourism.

To understand the change it is necessary to review the research into the Venetian period of Cretan history and above all the scholarly exploration of its monuments. The architectural remains of the long Venetian presence in Crete were first recognized as monuments by the Italian archaeological mission in the nineteenth century. Its director, Federico Halbherr, though he was on the island to discover the monuments of illustrious antiquity, felt that the Italian mission ought to have an expert in Venetian history, as Crete had preserved a large number of monuments from that period. As a result of his efforts Giuseppe Gerola arrived in Crete, sent by the Istituto Veneto di Scienze, Lettere ed Arti, with the aim of documenting the glory of the maritime state in the East. ${ }^{9}$ Over the course of two years he travelled all over the island, making a thorough search for Venetian works, copying inscriptions, drawing and photographing a large quantity of buildings. On his return to Italy Gerola cross-referenced his finds with the information in sources in the well-stocked Venetian archives. The results of his researches were published in the monumental, five-volume work Monumenti Veneti nell' isola di Creta between 1905 and 1940 and in a number of other studies. Gerola's book, which remains unsurpassed to this day in terms of its comprehensiveness, forms part of the scheme of national historiographies, such as the corresponding French works by Enlart ${ }^{10}$ on the monuments of the Lusignan period in Cyprus and by Gabriel on Rhodes under the Knights. ${ }^{11}$ From a Greek point of view there was no interest in these monuments before 1953 when, on the initiative of an individual, Andreas Kalokairinos, who also provided the funding, and with the moral and scholarly support of archaeologists, historians and writers who lived and worked in Crete, the Historical Museum of Crete and the Society for Cretan Historical Studies were founded. Their programmatic aim was to gather and study the evidence as regards Cretan history from the early middle ages up to the modern period. These goals resembled the initiatives taken by two academic institutions, the Historical and Ethnological Society and the Christian Archaeological Society, at the turn of the nineteenth century in Athens in order to set up museums which would link antiquity with the modern day. As a result of their efforts the National Historical Museum and the Museum of the Christian Archaeological Society (subsequently incorpo- 
rated into the Byzantine and Christian Museum in Athens in 1914) were founded. ${ }^{12}$

From the outset the main aim of the Society for Cretan Historical Studies and the Historical Museum of Crete was to collect and protect Venetian monuments in Crete. As Nikolaos Platon, head of the Archaeological Service in Crete, was taking part in this initiative (though himself a specialist in the Minoan civilization), the immediate transfer to the new museum of sculptures and architectural members from the Venetian period hitherto kept in the store-rooms of the Archaeological Museum was assured. The Historical Museum of Crete thus became the supreme exhibition space for displaying the medieval and Venetian monuments of Crete, as well as for documenting the more recent history of Crete. On the initiative of these same people San Marco, the church of the Venetian dukes of Crete, was then restored..$^{13}$ The restoration was carried out without archaeological and architectural documentation. Nevertheless it remains an indication of practical interest in the monuments of the Venetian period. Yet academic work on these monuments was slow to develop.

It was not until the seventies that there were signs of this sort of involvement, in the form of a series of studies seeking out the Italian models for architecture in Crete, or documenting the visits by Italian engineers to plan and execute the large fortification works of the sixteenth century. ${ }^{14}$ This had been preceded by a significant development in the fifties: the founding of the Hellenic Institute of Byzantine and Post-Byzantine Studies in Venice. This first Greek academic institution abroad, heir to the wealth and the premises of the former Greek community in the city, quickly became a centre for research into the Venetian archival sources on Greek history. With such an objective it is natural that research into the Venetian period in Crete should have been of primary importance. The Hellenic Institute in Venice inherited a collection of icons from the Greek community which it organized into a museum. Most of these icons had a Cretan provenance. The catalogue which Manolis Chatzidakis, an eminent Byzantine art historian, wrote on these icons ensured that they became more widely known in the international academic community. ${ }^{15}$

From as early as the inter-war years icons had occupied an interesting position in Greek historiography. Images painted on wooden panels, a characteristically Byzantine variety of portable picture, have a special place in the de- votional tradition of the Orthodox Church. The fact that icons are portable objects and that they have been preserved in large numbers led to their becoming collectible items from the early twentieth century, when an interest in Byzantine art first emerged. Though they retained the characteristic Byzantine style and above all the Byzantine technique of painting in tempera, most of these icons have been dated from the fifteenth century on. Despite the fact that they present a conspicuous faithfulness to Byzantine artistic tradition, they sparked off the connection between Byzantine art and European art. This was first mooted in the interpretative model of Angelos Prokopiou, then a young historian of art, developed in relation to eighteenthcentury art in the Ionian Islands, which had cut all ties with earlier artistic tradition and appropriated the ways of contemporary Italian painting. The Cretan icon painters, representatives of the Byzantine tradition, began in the sixteenth century under Venetian rule to adapt their painting to the tastes of a new urban public then emerging in Crete under the influence of the commercial metropolis and to apply some of the artistic triumphs of the Italian Renaissance in a selective fashion to their own work. When, after the Ottoman conquest of Crete in the seventeenth century, Cretan artists fled to the Venetian-occupied Ionian Islands, this tendency was enhanced and succeeding generations of artists were completely won over to Western European art. ${ }^{16}$ According to this model icon painting in the Venetian-dominated areas of Greece was promoted as the link between Byzantine, or medieval Greek, art and the modern culture of Western Europe. It was also in the inter-war years, though in other quarters, that the artistic values of the literature, which developed in the same period in Crete, began to be made much of. Consequently the years spent under Venetian rule were no longer thought of as a dark age of barbaric slavery, but on the contrary it was acknowledged that they had allowed a flowering of the arts and ensured the link between Greek and European culture. The term 'Cretan Renaissance' began to be used for this flowering of the arts and over time this denomination became imbued with connotations which identified it as a Greek version of the Italian Renaissance. ${ }^{17}$

The political and ideological importance of this reading of history is obvious. After World War II, and especially once Greek policy had become more oriented towards Europe in the years before Greece became a member of the European Community, it had significant resonance. 


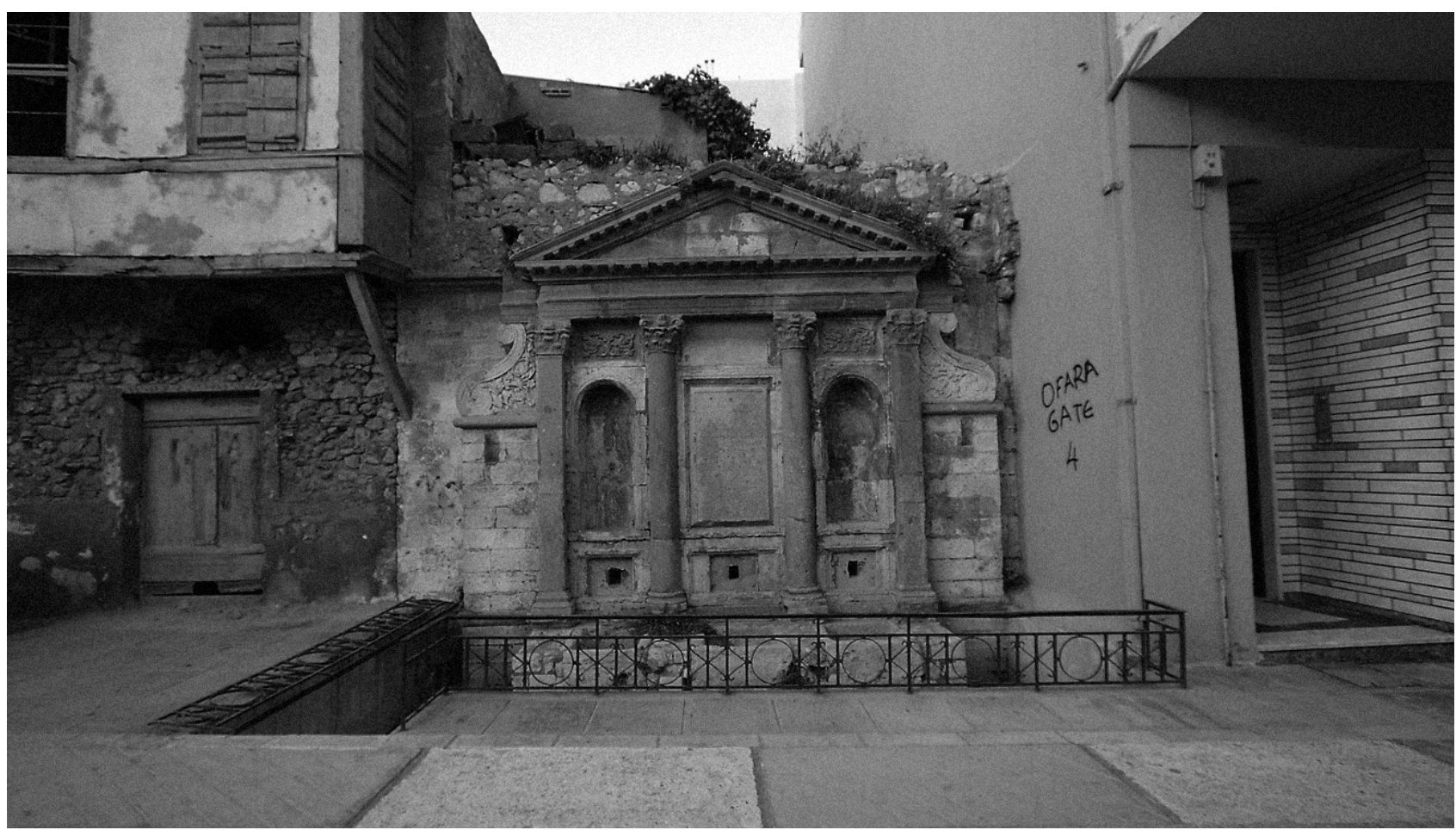

Fig. 12. Herakleion, Priuli Fountain, 1666 (photo: author).

Nevertheless this positive evaluation of the period of Venetian rule only influenced the policy on monuments very gradually and with difficulty. There have already been plans to protect individual monuments. However, the many surviving monuments from the Venetian period in Crete, some of which are massive and impressive, have yet to find their place within the Cretan historical landscape. Progress towards integrating them into the actual cityscape is slow (fig. 12), and academic research (and the corresponding restoration and preservation) are also lagging behind in this respect. Finally, incorporating them in the collective historical memory is proceeding at a snail's pace.

This time-lag is accounted for by reasons which go beyond the ideological presuppositions about historical periods or limits on funding, though both of these constitute real problems. On the one hand it relates to deficiencies in the policy on monuments, which to this day has not been related to policy on the use of space. On the other hand the exclusive concentration on Greek history in the educational system at all levels has something to answer for.

The average Greek who completed his schooling at 18 knows that Ictinus and Callicrates were the architects of the Parthenon and that Isidore of Tralles and Anthemios of Gaza built St Sophia in Constantinople. They are also certain that the latter is the most glorious monument of Hellenism and may be puzzled as to why it is not on Greek soil nowadays. But they do not know that there was an important architect called Andrea Palladio and that, apart from the wonderful buildings he created in his homeland of Italy, he produced plans which were copied elsewhere and indeed on a Greek island, Crete. It is doubtful whether the average Greek student of architecture or archaeology knows this even. European history and the history of European art has not yet been incorporated into the curriculum at all levels of education, leaving a lacuna in respect of these monuments which shed light on the European links in local histories. Thus appreciation of the monuments from the Venetian period can only be limited. Safeguarding them is consequently still controversial and their management remains a complex issue.

The result is eloquently illustrated in figure 12 . The overwhelming change in the urban space obviously needs more complex measures than just conservation of the 
monumental fabric itself. Most surviving monuments of the Venetian period need to be handled in relation to the built environment of the town. However, this is a matter for authorities other than the Archaeological Service. In this respect Venetian monuments share the fate of a large number of historical monuments dating from early modern and more recent times which deserve to be protected and safeguarded. The whole legal apparatus as well as the authorities and institutions responsible for safeguarding the Greek architectural heritage are structured with

\section{Notes}

1. On Zambelios, see Herzfeld 1986, 39-52.

2. 'In those days a dazzling diadem of towers, battlements, ramparts and crescent bastions - a crown of thorns - encircled her noble brow and constricted her lungs.' (Zambelios 1871).

3. Law 'on scientific collections ... and antiquities', 1834, part III, article 1 (Petrakos 1982, 132).

4. The Market in Chania, a genuine contribution to modern town planning, destroyed a monumental part of the 16th c. Venetian walls. Built in the late, modernizing phase of Ottoman domination, in the corresponding location on the borderline between the old and new towns, just outside the Venetian walls, the Rethymnon market was itself destroyed in the 20th c. in order to create an appalling square. It should be noted that the development and spread of towns was so rapid that it outpaced any town-planning considerations.

5. Manolis Borboudakis who, as a young Curator of Antiquities in Herakleion, had opposed the demolition.

6. Gerola 1917, 35-60.

7. Gerola 1908, 112-17.

8. This policy continues to this day. Since the early nineties the little Franciscan church of San Salvatore in Chania antiquities in mind. The concept of the historical urban ensemble, although a useful instrument in modern urban planning, is absent from the legislation on monuments, though this has been reconsidered recently. It is also neglected in conservation practice.

\section{Olga Gratziou}

Department of History and Archaeology

University of Crete

gratsiou@phl.uoc.gr has housed the Byzantine archaeological collection, though the monastery's medieval cloister (the only surviving example in Greece) has not yet been restored to it because it has not be possible to expropriate its current owners. The planned move of the Chania Archaeological Museum to a modern building will in the years to come once again pose the question of how to use St Francis, but above all it will offer the opportunity to research parts of its building history which have not yet been destroyed.

\section{Curuni 1988.}

10. Enlart 1899.

11. Gabriel 1921-1923. See also Gerola 1930; Balducci 1931.

12. Gratziou 2006.

13. Parlamas et al. 1958.

14. Dimakopoulos 1970; Dimakopoulos 1970-1972; Dimakopoulos 1972; Dimakopoulos 1977. Fatourou-Hesychaki 1972; Fatourou-Hesychaki 1983; Steriotou 1992.

15. Chatzidakis 1962.

16. Procopiou 1939.

17. Hadjinicolaou 2000. 


\section{REEFERENCES}

Balducci H. 1931: Orme del rinascimento italiano in Rodi al tempo dei Cavalieri (Pavia).

Curuni S.A. 1988: L' Istituto Veneto di Scienze, Lettere ed Arti e la missione cretese di Giuseppe Gerola, in: Curuni S.A. \& Donati L. (eds), Creta Veneziana (Venice) 37-113.

Chatzidakis M. 1962: Icônes de Saint-Gerges des Grecs et la collection de l'Institut Hellénique de Venise (Venice).

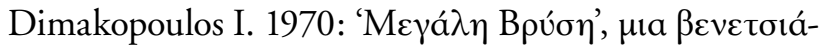

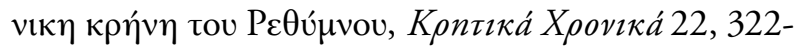
43.

Dimakopoulos I. 1970-1972: O Sebastiano Serlio ota

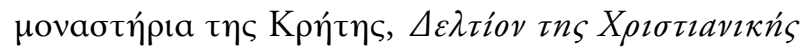

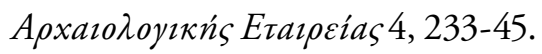

Dimakopoulos I. 1972: A Mannerist portal at Rethymno after a drawing by Sabastiano Serlio, A

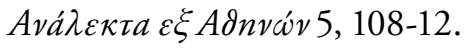

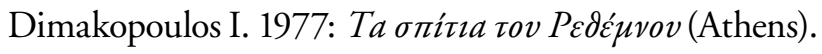
Enlart C. 1899: L'art gothique et la Renaissance en Chypre (Paris).

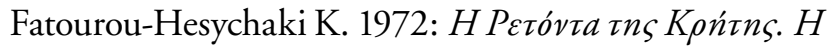

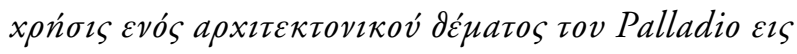

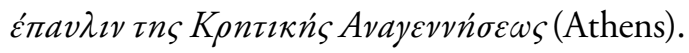

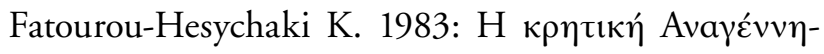

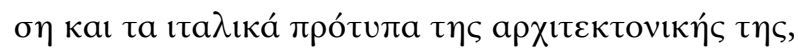

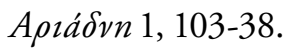

Gabriel A. 1921-1923: La cité de Rhodes (Paris).
Gerola G. 1905-1932: Monumenti Veneti nell' isola di Creta (1905: vol I 1- I 2; 1908: vol. II; 1917: vol. III; 1932: vol. IV; Venice).

Gerola G. 1930: Il contributo dell' Italia alle opere d' arte militare rodiesi, Atti del Reale Istituto Veneto di Scienze, Lettere ed Arti 89, 1015-27.

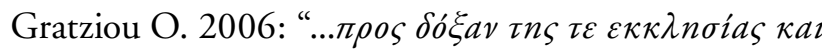

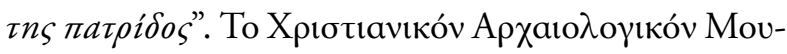

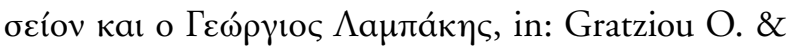

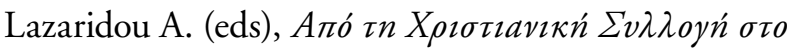

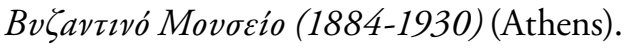

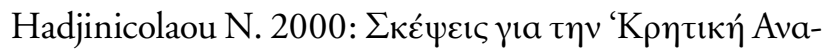

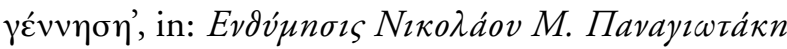
(Herakleion) 777-812.

Herzfeld M. 1986: Ours Once More: Folklore, Ideology, and the Making of Modern Greece (New York).

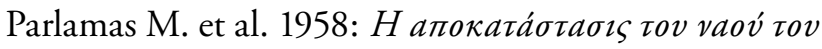

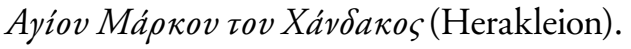

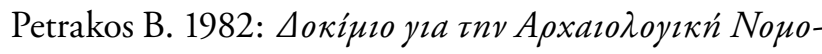

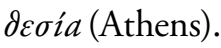

Procopiou A. 1939: La peinture religieuse dans les îles ioniennes pendant le XVIIIe siècle. Essai sur la transformation de la peinture byzantine en baroque (Paris).

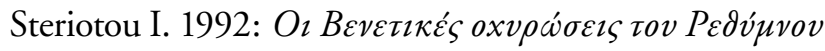

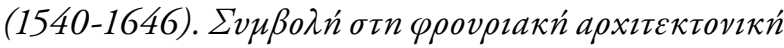
cov $160 v$ ka oov 17 ov arẃva (Athens).

Zambelios S. 1871: Konııкoi Гáuoı (Athens). 